\title{
Mind over matter: perceptions behind the impact of jaguars on human livelihoods.
}

\author{
SILVIO MARCHINI ${ }^{\mathrm{a}, \mathrm{b}}$ and DAVID W. MACDONALD \\ a. Forest Science Department, Luiz de Queiroz College of Agriculture, University \\ of São Paulo,Rua 2, 624.Piracicaba, SP 13420-861,Brazil. \\ b. Wildlife Conservation Research Unit, The Recanati-Kaplan Centre, Department of Zoology, \\ University of Oxford, Tubney House,Abingdon Road, Tubney, UK. OX13 5QL, United \\ Kingdom.
}

silvio.marchini@usp.br (corresponding author), david.macdonald@zoo.ox.ac.uk

\begin{abstract}
In an investigation of perceptions of the conflicts between people and jaguars on the Amazon deforestation frontier and Pantanal, Brazil, we explored how perceptions of the impact of jaguars on livestock and on human safety vary with experience of jaguars (including reported livestock loss), region, place of residence, attitudes towards jaguars, knowledge of the species, and perceptions of changes in jaguar abundance and the regional economic situation. Livestock loss and threat to human safety were not the only predictors of the perceived conflict with jaguars. Livestock loss acted in combination with attitudes, knowledge and perceptions of the economic situation to determine how people perceive the impact jaguars have on their livelihoods. Attitudes and knowledge were influenced by age, gender and whether respondents lived in urban or rural areas. An experiment in which respondents were shown photographs of dead livestock, and asked to ascribe the cause of death, revealed an interaction between attitudes and knowledge: of respondents whose knowledge of the species was low, those with negative attitudes towards jaguars assigned a larger number of photographs to jaguar depredation. Our evidence suggests that attitudes and knowledge can affect the conclusions a rancher draws from finding the carcass of a cow, or even from noticing that a cow is missing. The owners of smaller holdings believed that depredation was more serious on neighboring properties than on their own, which suggests that their perceptions of conflict with jaguars were shaped primarily by what is heard from other people, and not by personal experience.
\end{abstract}




\section{Introduction}

Jaguars (Panthera onca) often kill livestock and in some rare circumstances they can attack humans, both leading to severe persecution (Jędrzejewski et al., 2017). Killing jaguars is one of the most serious threats to their survival (Zeller, 2007; Galetti et al., 2013). Together with habitat loss, persecution has reduced jaguars to $46 \%$ of their historical range (Sanderson et al., 2002). Brazil arguably contains the largest population of jaguars, and it encompasses the two largest strongholds for the species (Sanderson et al., 2002): the Amazonian rainforests and the wetlands of the Pantanal. In both Amazonia and the Pantanal, jaguars occur mostly outside of protected areas. Strictly protected areas account for about 8.3\% of the Brazilian Amazon (Ferreira et al., 2014) and 2.9\% of the Pantanal territories. Most encounters between people and jaguars in Amazonia and Pantanal, and certainly in the other Brazilian biomes, take place in rural contexts. Therefore, the future of jaguars is likely to be tightly linked to the perceptions of Brazilian rural residents. However, despite the rapid growth of our understanding and acknowledgement of the role of social and psychological factors in determining human tolerance and behavior towards wildlife in general (Manfredo 2008; Kansky et al., 2016), and carnivores in particular (Dickman et al., 2013; Bruskotter and Wilson, 2013; Treves and Bruskotter, 2014), little is known about the relationship between actual livestock loss and perceived impacts associated with jaguars. In conflicts between people and carnivores, the perceived impacts often exceed the actual evidence (Conover 2002, Marchini and Macdonald 2012). Such imprecise relationship between reality and perception could prove perilous to a threatened species, rendering ineffective many biologically based conservation and management actions (Cavalcanti et al. 2010). In the meantime, recommendations for conservation and conflict mitigation still emphasize the importance of retaliatory and preventive killing (Galetti et al., 2013).

Early studies on local perceptions of jaguars in Brazil assessed the role of sociodemographic factors in human-jaguar conflict (Conforti and Azevedo, 2003; Michalski et al., 2006; Palmeira and Barrela, 2007; Santos et al.,2008; Marchini and Crawshaw, 2015). Among the 50 landowners interviewed in northern Pantanal by Zimmermann et al. (2005), attitudes towards jaguars were more closely related to respondents' age and relative wealth than to cattle losses, with younger and wealthier ranchers holding more positive attitudes towards them. Also in the Pantanal, Porfirio et al. (2014) interviewed 50 riverside inhabitants and found that the negative perceptions of jaguars were related to people's safety and not to economic losses from livestock depredation. Marchini and Macdonald (2012) examined the influence of peers and social norms on poaching intentions. Based on interviews with 268 cattle ranchers in Amazonia and Pantanal, they concluded that social factors were more influential than retaliation for jaguar predation on cattle or perceived threats to humans. The ranchers' intentions to kill jaguars positively correlated with the size of their land holdings and were best explained by social norms; ranchers who believed that others kill jaguars or expected such poaching had a stronger intention to kill jaguars themselves. Altogether these studies revealed strong and contradictory attitudes toward the species and, along with our previous results (Cavalcanti et al., 2010), suggest that the perceived impact of jaguars on human livelihoods may often exceed the evidence.

We assessed peoples' perceptions of the impact of jaguars on livelihoods in Amazonia and the Pantanal, and explored relationships between these perceptions and socio-economic variables such as age, gender, place of residence (urban/rural) and property size, plus psychological variables such as experiences, attitudes and knowledge about jaguars. We hypothesized that perceptions of jaguar impact on human livelihoods are not explained solely by the loss of livestock to jaguars, or by attacks on humans, but socio-economic and psychological factors as well. Given the socio-economic and cultural differences between the Amazon deforestation frontier and the Pantanal (see below), we expected cattle ranchers in the two study areas to differ in their perceptions of the impact of jaguars on their livelihoods, irrespective of the damage posed by jaguars (Hypothesis 1). We also expected that perceptions of the impact of 
jaguars on livelihoods and attitudes to jaguars would not differ between cattle ranchers - who are exposed to both livestock loss and personal damage by jaguars - and farmers - who are exposed to personal damage but not livestock loss (Hypothesis 2). Furthermore, we hypothesized that the perceived impact of the jaguar on human safety would not be necessarily greater among rural residents - who are potentially exposed to the attack by jaguars - than among urban residents - who are not (Hypothesis 3). We expected negative experiences with jaguars (i.e. attack of jaguars on livestock and people) to determine perceptions of jaguar impact on livestock and human safety (Hypothesis 4). However, we hypothesized that attitudes toward jaguars and knowledge about the species would also influence these perceptions (Hypothesis 5). Age, gender and property size were expected to indirectly affect perceptions of impact by their effect on attitudes and knowledge (Hypothesis 6). To investigate further the role of negative experiences versus attitudes and knowledge in determining perceptions of jaguar impact on livestock, we conducted an experiment in which respondents were asked to interpret photographs of dead cattle and assign the most likely cause of death. We hypothesized that respondents with stronger negative attitudes to jaguars and less knowledge about them would assign more photographs to jaguar predation (Hypothesis 7).

\section{Materials and methods}

\subsection{Study areas and participants}

This study was conducted in Amazonia and Pantanal (Fig. 1). In Amazonia we worked in the districts of Alta Floresta and Novo Mundo, on the frontier of deforestation in the north of the state of Mato Grosso, southern Amazonia. Alta Floresta was founded in 1976 and colonized by migrant farmers, mostly from southern Brazil. Today, its economy is based primarily on cattle ranching, timber extraction and agriculture, although $80 \%$ of Alta Floresta's approximately 50,000 inhabitants live in its urban area (Brazilian Institute of Geography and Statistics, 2016). The district hosts a sizable cattle herd (over 716,000 head) (Brazilian Institute of Geography and Statistics, 2016). Cattle depredation by jaguars is considered severe (Michalski et al., 2006), and persecution and habitat loss are major threats to jaguars in Alta Floresta (Michalski and Peres, 2005). Novo Mundo has around 8,500 inhabitants, many of them small-scale landowners recently arrived from other parts of Mato Grosso. The district is home to over 349,000 head of cattle. Alta Floresta and Novo Mundo together host the Cristalino State Park, one of the most important protected areas on the deforestation frontier, despite its relatively small size (184,900 ha). Properties surveyed in Amazonia were located between $9^{\circ} 23^{\prime} 2.13^{\prime \prime} \mathrm{S}$ and $9^{\circ} 49^{\prime} 30.86^{\prime \prime S}$ and $56^{\circ} 20^{\prime} 25.59^{\prime \prime} \mathrm{W}$ and $55^{\circ} 25^{\prime} 25.36 " \mathrm{~W}$.

In the Pantanal, we worked in the neighbouring districts of Cáceres and Poconé, in the south of the state of Mato Grosso. Cáceresand Poconé have approximately 90,000 and 32,000 inhabitants respectively. The Pantaneirolandowner is typically from long-established, landowning dynasties, and cattle ranching is their main economic activity (Brazilian Institute of Geography and Statistics, 2016). As with the Amazon frontier, northern Pantanal hosts large cattle herds (around 1,000,000 and 477,000 head in Cáceres and Poconé, respectively; Brazilian Institute of Geography and Statistics, 2016) and depredation attributed to jaguars is a major cause of complaint by the local ranchers (Marchini, 2003; Zimmermann et al., 2005). Ranches surveyed in the Pantanal were located between $16^{\circ} 14^{\prime} 54.69^{\prime \prime} \mathrm{S}$ and $17^{\circ} 26^{\prime} 58.17^{\prime \prime} \mathrm{S}$ and $58^{\circ} 18^{\prime} 5.40^{\prime \prime} \mathrm{W}$ and $56^{\circ} 22^{\prime} 28.04^{\prime \prime} \mathrm{W}$.

In both study areas, rural and urban residents were surveyed. In rural areas, the sample unit was the property, with either owner - wife or preferably husband - from each surveyed (in a few large ranches, the ranch manager was interviewed when neither of the owners were available). The Association of Rural Workers of Alta Floresta, Cáceres and Poconé provided a list of members, with landowner's name and contact information, from which we could randomly select ranches. However, the lists were not comprehensive. The lack of property registers was particularly pronounced in the settlements around Cristalino State Park in the municipality of Novo Mundo. Therefore, a combination of techniques was added to ensure 
randomness and representativeness. Google Earth imagery (Google Inc., 2009) was used to map all the roads within the study areas (available road maps do not include minor roads). A systematic sampling strategy was then used on each road, selecting every other property along the road. In Amazonia, ranches were easily accessible by land and all interviews were carried out on site, while in the Pantanal some properties near the Transpantaneira highway could be visited but many others were inaccessible overland. Hence, many ranchers were interviewed in their second residences in town. In Amazonia, properties where the main economic activity was non-stock agriculture were also included in the survey. Urban residents were interviewed in Alta Floresta and Poconé. On the most central streets of each town, we selected every fifth home or shop until 50 owners in each study area had been interviewed. Suitable sample sizes were determined based on the detection of the examined effects (i.e. survey terminated when the tested differences or associations between variables were detected) and practical considerations (e.g. time available). Although we used different sampling methods to reach these target groups, we achieved high response rates from each group (97-100 percent; some ranchers in the Pantanal who were randomly selected from the sampling frame could not be contacted), and results from our survey can be generalized to other parts of the Amazon deforestation frontier and Pantanal.

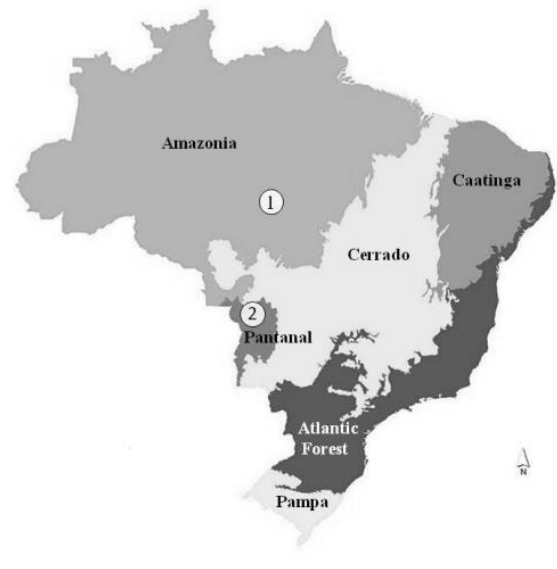

Fig. 1. Map of Brazil showing major biomes and study areas: (1) southern Amazonia and (2) northern Pantanal.

\subsection{Data collection}

The study was conducted between March and October 2009 (Amazonia) and between February and May 2010 (Pantanal). Face-to-face interviews were used. Conflict with jaguar can be a sensitive issue in rural areas, and some respondents may have held negative attitudes towards individuals and institutions that advocate wildlife conservation. Such attitudes can be stronger towards people and institutions perceived as foreign to the region (Marchini, 2003). Therefore, some measures were taken to avoid response and interviewer biases. All interviews were conducted by first author, who is Brazilian. He was always accompanied by a male local field assistant during the interviews, was as objective and neutral in appearance and behavior as possible, and explained to respondents that the purpose of the survey was to collect data on people's perceptions of wildlife, and that these would ultimately contribute to a renowned local educational project of which he was the coordinator.

We conducted a pilot study using qualitative, semi-structured interviews with 130 people (90 rural and urban residents in Amazonia, and 10 ranchers and 30 urban residents in the Pantanal). By listening to people talk freely, we were able to identify salient beliefs, 
perceptions, and peculiarities of the local parlance, which were then used in the design of the questionnaire, and in adjusting our language to the target groups. During the piloting process, open-ended questions were replaced incrementally by clear, quantitative questions that would produce data suitable for statistical analysis. Perceptions of jaguar impact on human livelihood were assessed by questions that were designed to evaluate beliefs about past damage, vulnerability and perceptions of risk of future damage at different geographical (ranch / neighborhood / district) and demographic (personal / family /community) scales. Exploratory factor analysis revealed that perceptions of jaguar impact on human livelihood could be described using two scales representing 'perception of jaguar impact on livestock' (identified by Factor 1) and 'perception of jaguar impact on human safety' (identified by Factor 2). We used Cronbach's alpha to improve the internal coherence of the scale by discarding items to maximize the alpha value (Vaske 2008).

Ultimately we designed a structured interview (Oppenheim, 1998) to examine the following: (1) perception of jaguar impact on livestock; (2) perception of jaguar impact on human safety; (3) experience of jaguars: livestock loss, acquaintance with injured person, and sighting; (3) attitude towards jaguars (i.e. favorability/unfavorability towards the species); (4) knowledge about jaguars and depredation; (5) socio-demographic variables: age, gender, and education; and (6) property size. Two elements that emerged from the initial semi-structured interviews were also incorporated: perceptions of (7) change in jaguar abundance and (8) the regional economic situation. The variables are described in more detail in Table 1. 
Table 1. Variables addressed, survey questions and response categories used to assess them, and their reliability (Cronbach's alpha: $\alpha$ ).

\begin{tabular}{|c|c|c|}
\hline Variable/Survey Question & Response categories & $\alpha$ \\
\hline Perception of jaguar impact on livestock & $0=$ None & 0.88 \\
\hline Damage associated with depredation ever caused by jaguars to you. & $1=$ Very small & \\
\hline Damage associated with depredation ever caused by jaguars to your & $\begin{array}{l}2=\text { Small } \\
3=\text { Medium }\end{array}$ & \\
\hline $\begin{array}{l}\text { neighbors. } \\
\text { Risk of any damage associated with denredation to you in the next } 12\end{array}$ & 4 = High & \\
\hline 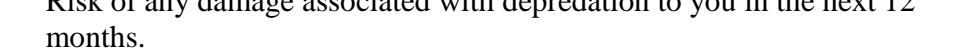 & $5=$ Very high & \\
\hline \multicolumn{3}{|l|}{$\begin{array}{l}\text { Risk of any damage associated with depredation to your neighbors in the } \\
\text { next } 12 \text { months. }\end{array}$} \\
\hline Perception of jaguar impact on human safety & $0=$ None & 0.86 \\
\hline Number of people ever hurt by a jaguar in the neighborhood. & $1=$ Very small & \\
\hline Number of family members ever hurt by a jaguar. & $2=$ Small & \\
\hline Risk of you being hurt by a jaguar in the next 12 months. & $3=$ Medium & \\
\hline Risk of a family member being hurt by a jaguar in the next 12 months. & $\begin{array}{l}4=\text { High } \\
5=\text { Very high }\end{array}$ & \\
\hline \multicolumn{3}{|l|}{ Experience of jaguars } \\
\hline What percentage of your herd was lost to jaguars in the last 12 months? & Fill-in-the-blank & \\
\hline $\begin{array}{l}\text { How many people do you personally know that have been injured/killed } \\
\text { by a jaguar? }\end{array}$ & Fill-in-the-blank & \\
\hline How many times have you seen a live jaguar in the wild in your life? & Fill-in-the-blank & \\
\hline Attitude to jaguars & & 0.93 \\
\hline You would like the jaguar population in the region to: & $\begin{array}{l}-2=\text { decrease a lot } \\
-1=\text { decrease } \\
0=\text { doesn't change } \\
1=\text { increase } \\
2=\text { increase a lot }\end{array}$ & \\
\hline If all the jaguars disappeared forever from the region, you would feel: & $\begin{array}{l}-2=\text { very happy } \\
-1=\text { happy } \\
0=\text { indifferent } \\
1=\text { sad } \\
2=\text { very sad }\end{array}$ & \\
\hline What you feel towards jaguars is better described as: & $\begin{array}{l}-2=\text { dislike } a \text { lot } \\
-1=\text { dislike } \\
0=\text { indifferent } \\
1=\text { like } \\
-2=\text { like a lot }\end{array}$ & \\
\hline The jaguar has its value, even if it does not generate any income to you: & $\begin{array}{l}-2=\text { strongly disagree } \\
-1=\text { disagree } \\
0=\text { neutral } \\
1=\text { agree } \\
2=\text { strongly agree }\end{array}$ & \\
\hline
\end{tabular}


Table 1. Continuation.

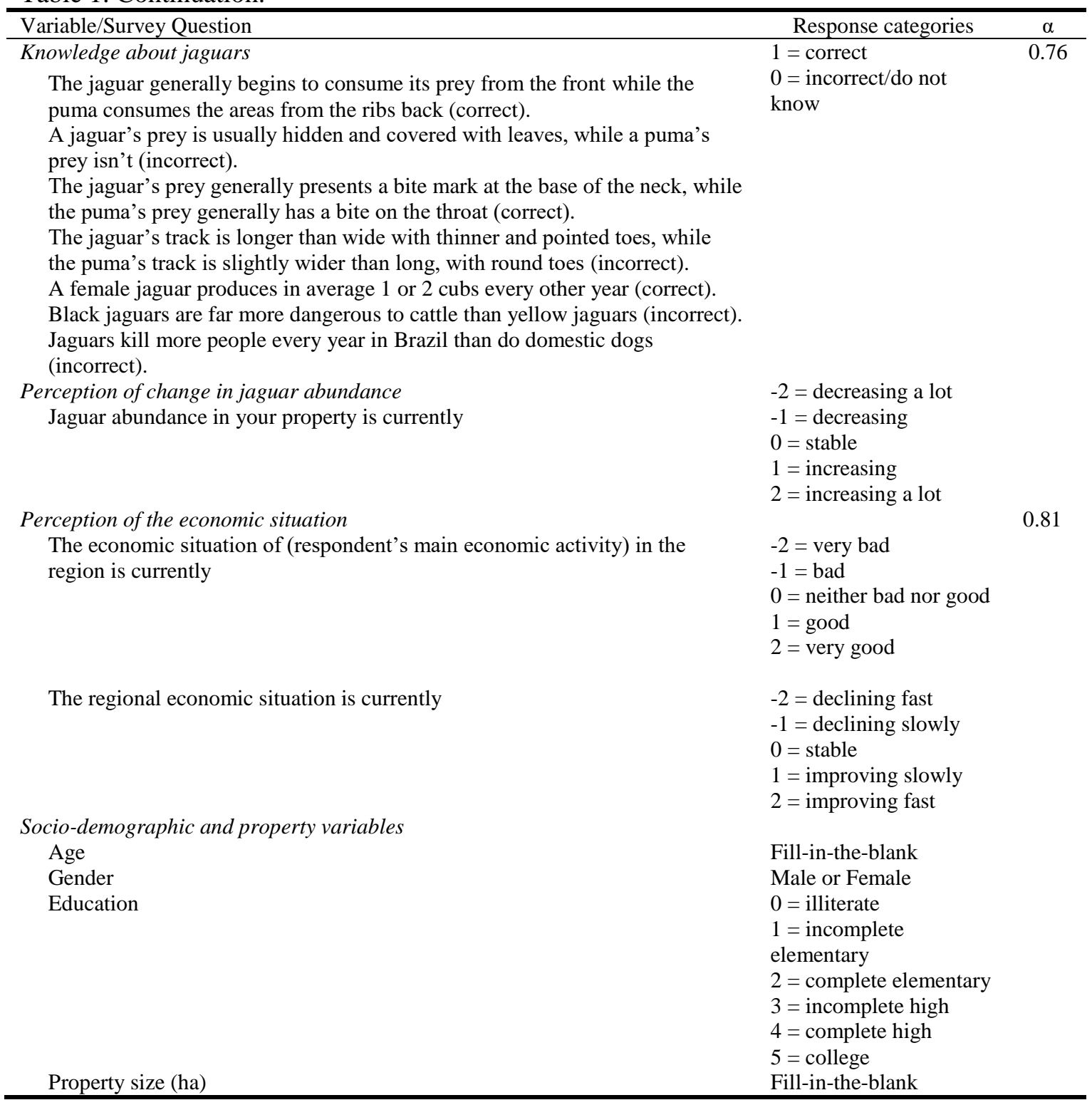

\subsection{Photograph interpretation experiment}

In addition to the main interview survey, a stratified random sub-sample of respondents (55 ranchers in Amazonia and 15 in the Pantanal) was asked to interpret a set of 10 photographs of dead cattle. Four of the photographs presented evidence of predation by jaguar, three presented evidence of predation by puma, and three did not present evidence of predation by any particular predator. Photographs measured approximately $13 \times 21 \mathrm{~cm}$ and were laminated in transparent plastic. They were handed to the respondents one by one in a random order. Respondents were given enough time to examine each photograph before being asked the following open-ended question: What was the cause of the death of this animal? Answers were coded as dichotomous variables, using 1 for any kind of reference to predation by jaguar and 0 for other causes and "do not know". Whether the answer was correct or not was not taken into account, as the experiment was not intended to measure respondents' knowledge about depredation but rather to explore the effects of experience, attitudes and knowledge on their interpretation of the photographs. 


\subsection{Data analysis}

Statistical analyses were run in SPSS 16, version 14 (2005). General linear models, post-hoc Tukey tests and $\chi 2$ tests were used to examine broad differences in survey variables between sample group means (Tables 2 and 3). Pearson correlation coefficients were used to examine the correlations between predictor variables and perceptions of jaguar impact on human livelihoods among cattle ranchers in Amazonia and the Pantanal. Next two sets of General Linear Models (GLM) were performed to develop a predictive model of perception of jaguar impact on human livelihoods for ranchers in the two study areas. The first GLM analysis examined the prediction of perceptions of jaguar impact on livestock and human safety. Instead of an automated stepwise procedure, a structured comparison of specific models defined a priori based on different explanation of perceptions of impact was carried out. Sequential sum of squares (type I models) were used so that each effect in an individual model adjusted only for preceding effects in the model. The following models were assessed: (Model 1) negative experiences with jaguars: loss of livestock to jaguars and acquaintance with people who had been injured by a jaguar, (Model 2) significant predictors of Model 1 plus psychological variables: attitude towards jaguars, knowledge about jaguars and depredation, sighting of jaguars in the wild, perception of increase in jaguar abundance and perception of economic situation, and (Model 3) significant predictors of Model 2 plus socio-economic variables: age, gender, education and property size. The second set of GLM examined the effect of the socio-economic variables on the negative experiences and psychological variables that significantly affected perceptions of jaguar impact on human livelihoods in the first GLM analysis. General linear models were also used to examine the effect of knowledge, attitudes, and reported livestock loss on the number of photographs attributed to jaguar depredation in the photograph interpretation experiment.

\section{Results}

\subsection{Characteristics of sample}

We conducted a total of 463 interviews including 52 in urban Pantanal, 50 in urban Amazonia, 48 in rural Pantanal and 313 in rural Amazonia. The rural Amazonia sample included 92 properties where agriculture was the main economic activity and no cattle were raised. Table 2 presents additional sample characteristics.

\subsection{Perceptions of jaguar impact on human livelihoods}

In support of Hypothesis 1, cattle ranchers in Amazonia and the Pantanal differed in their perceptions of the impact of jaguars on their livelihoods. Perceived jaguar impact on livestock was significantly greater among ranchers in the Pantanal than in Amazonia (Table 2). Owners of smaller landholdings (by area) tended to perceive a higher impact of jaguar predation on their neighbors' ranches than they did on their own ranch. This discrepancy between perceived impacts on neighbors' versus own ranch decreased with increasing property size (Pearson correlation; $\mathrm{r}=-0.522, \mathrm{p}<0.001$ ).

Perceived jaguar impact on human safety differed significantly between ranchers in Amazonia and the Pantanal, with the latter holding the lowest perception of impact among the five groups. In rural Amazonia, cattle ranchers and farmers did not differ in their perception of jaguar impact on human safety, in accordance with Hypothesis 2. Urban residents in Amazonia had the strong perceptions of jaguar impact on human safety, supporting Hypothesis 3.

\subsection{The effect of region, land use, and place of residence}

\subsubsection{Negative experiences with jaguars}

Reported livestock loss was greater in the Pantanal ( $2.2 \%$ of cattle holdings) than in Amazonia $(0.9 \%)$. Not all of the reported livestock loss to jaguars was associated with 
depredation. Twelve per cent of the ranchers in Poconé believed that jaguars caused cattle to die by scaring them out of the 'capões' (dry forest patches where cattle find refuge during floods), into flooded areas, where they either drowned or became stuck in the mud and starved to death. This purported indirect jaguar-induced mortality of livestock was not confirmed by field observation. Accounts of people who had been injured by a jaguar were most frequent in the Pantanal. It seemed that the great majority of accounts referred to just two particular stories of injury caused by jaguars, one in each study site, that happened over 5 years earlier. In Amazonia, the victim would have been attacked during the night, while sleeping in his hammock, whereas in the Pantanal he would have been attacked when unwittingly approaching a carcass upon which the jaguar was feeding. The first author personally met and interviewed the two victims who confirmed the stories.

\subsubsection{Psychological variables}

Attitudes towards jaguars differed significantly between places of residence, with urban citizens having more positive attitudes towards the species. In rural Amazonia, ranchers and farmers did not differ in their attitudes to jaguars, in support of Hypothesis 2 (Table 2).

Ranchers in the Pantanal knew more about jaguars and depredation than did ranchers in Amazonia. Amazon ranchers were, in turn, more knowledgeable about jaguars and depredation than farmers in the same region. Urban residents in Amazonia and the Pantanal had lower levels of knowledge than ranchers and did not differ from each other in their levels of knowledge. A far greater percentage of people reported seeing a jaguar in the wild in rural Pantanal (90\%) than anywhere else. While $27 \%$ of the cattle ranchers in the Pantanal had lost count of the number of times they had seen a jaguar, $82 \%$ of those people in other groups who had ever seen a jaguar, had seen one only once (and typically only a glimpse). Perceptions regarding both changes in jaguar abundance and the regional economic situation differed significantly across the three rural groups. Cattle ranchers in the Pantanal reported the largest increases in jaguar numbers and the gloomiest economic situation, whereas Amazon farmers held the least negative perceptions of the economic situation and believed that jaguar numbers were declining in the region. 
Table 2. Summary statistics for each variable and results of general linear models, Tukey tests and $\chi^{2}$ test comparing variables among sample groups $(\mathrm{p}<0.05$; groups indicated by the same letter were not significantly different).

\begin{tabular}{|c|c|c|c|c|c|c|c|c|c|}
\hline & & \multicolumn{5}{|c|}{ Group $(n)$} & \multirow[b]{4}{*}{$\mathrm{df}_{\text {factor }}$} & \multirow[b]{4}{*}{$\mathrm{df}_{\mathrm{errror}}$} & \multirow[b]{4}{*}{$\mathrm{F} / \chi^{2}$} \\
\hline & & & & & Rural & & & & \\
\hline \multirow{2}{*}{\multicolumn{2}{|c|}{ Variable (unit or scale) }} & & & Non-ranchers & & ters & & & \\
\hline & & $\begin{array}{c}\text { Amazon } \\
(\mathrm{n}=50)\end{array}$ & $\begin{array}{c}\text { Pantanal } \\
(n=52)\end{array}$ & Amazon $(\mathrm{n}=92)$ & $\begin{array}{l}\text { Amazon } \\
(\mathrm{n}=220)\end{array}$ & $\begin{array}{c}\text { Pantanal } \\
(\mathrm{n}=48)\end{array}$ & & & \\
\hline $\begin{array}{l}\text { Age } \\
\text { (years) }\end{array}$ & $\begin{array}{c}\text { Range } \\
\text { Mean } \pm \text { SD }\end{array}$ & $\begin{array}{c}21 \text { to } 74 \\
44.0 \pm 13.0^{\mathrm{a}}\end{array}$ & $\begin{array}{c}18 \text { to } 66 \\
37.5 \pm 10.5^{\text {a }}\end{array}$ & $\begin{array}{c}17 \text { to } 77 \\
43.4 \pm 13.1^{\mathrm{a}}\end{array}$ & $\begin{array}{c}17 \text { to } 82 \\
42.4 \pm 13.1^{\text {a }}\end{array}$ & $\begin{array}{c}27 \text { to } 77 \\
54.8 \pm 11.8^{\text {b }}\end{array}$ & 4 & 452 & $\begin{array}{c}10.39 \\
p<0.001\end{array}$ \\
\hline $\begin{array}{l}\text { Gender } \\
\text { (male/female) }\end{array}$ & Male \% & 76.0 & 59.6 & 72.8 & 73.3 & 100.0 & 4 & - & $\begin{array}{c}22.98 \\
p<0.001\end{array}$ \\
\hline $\begin{array}{l}\text { Education } \\
(0 \text { to } 5)\end{array}$ & $\begin{array}{c}\text { Range } \\
\text { Mean } \pm \text { SD }\end{array}$ & $\begin{array}{c}1 \text { to } 5 \\
2.68 \pm 0.88^{\text {ac }}\end{array}$ & $\begin{array}{c}1 \text { to } 4 \\
3.06 \pm 0.94^{\mathrm{a}}\end{array}$ & $\begin{array}{c}0 \text { to } 3 \\
0.96 \pm 0.55^{\mathrm{b}}\end{array}$ & $\begin{array}{c}0 \text { to } 5 \\
1.26 \pm 0.76^{\mathrm{b}}\end{array}$ & $\begin{array}{c}0 \text { to } 5 \\
2.29 \pm 1.43^{\mathrm{c}}\end{array}$ & 4 & 458 & $\begin{array}{c}87.85 \\
p<0.001\end{array}$ \\
\hline $\begin{array}{l}\text { Property size } \\
\text { (ha) }\end{array}$ & $\begin{array}{c}\text { Range } \\
\text { Mean } \pm \text { SD }\end{array}$ & $\begin{array}{c}2.08 \pm 0.88^{\circ} \\
-\end{array}$ & $\begin{array}{c}3.06 \pm 0.94 \\
-\end{array}$ & $\begin{array}{l}0.90 \pm 0.55^{\circ} \\
2.4 \text { to } 144 \\
33.922 .9^{\mathrm{a}}\end{array}$ & $\begin{array}{c}1.26 \pm 0.76^{\circ} \\
2.4 \text { to } 21,600 \\
298.81,581.1^{a}\end{array}$ & $\begin{array}{c}2.29 \pm 1.43^{\mathrm{b}} \\
750 \text { to } 27,000 \\
5,524.05,342.4^{\mathrm{b}}\end{array}$ & 2 & 358 & $\begin{array}{c}p<0.001 \\
153.77 \\
p<0.001\end{array}$ \\
\hline $\begin{array}{l}\text { Perception of } \\
\text { jaguar impact on } \\
\text { livestock } \\
(0 \text { to } 20)\end{array}$ & $\begin{array}{c}\text { Range } \\
\text { Mean } \pm \text { SD }\end{array}$ & - & - & - & $\begin{array}{c}0 \text { to } 15 \\
2.52 \pm 2.61\end{array}$ & $\begin{array}{c}2 \text { to } 14 \\
7.58 \pm 2.89\end{array}$ & 1 & 267 & $\begin{array}{c}142.79 \\
p<0.001\end{array}$ \\
\hline $\begin{array}{l}\text { Perception of } \\
\text { jaguar impact on } \\
\text { human safety } \\
(0 \text { to } 20)\end{array}$ & $\begin{array}{c}\text { Range } \\
\text { Mean } \pm \text { SD }\end{array}$ & $\begin{array}{c}8 \text { to } 20 \\
15.84 \pm 2.49^{\mathrm{a}}\end{array}$ & $\begin{array}{c}4 \text { to } 16 \\
12.23 \pm 2.82^{b}\end{array}$ & $\begin{array}{c}4 \text { to } 16 \\
12.59 \pm 2.64^{b}\end{array}$ & $\begin{array}{c}6 \text { to } 18 \\
11.82 \pm 2.37^{b}\end{array}$ & $\begin{array}{c}2 \text { to } 20 \\
10.29 \pm 3.57^{c}\end{array}$ & 4 & 458 & $\begin{array}{c}31.58 \\
p<0.001\end{array}$ \\
\hline
\end{tabular}




\begin{tabular}{|c|c|c|c|c|c|c|c|c|c|}
\hline $\begin{array}{l}\text { Experience: } \\
\text { Livestock loss } \\
\text { (\% of holdings) }\end{array}$ & $\begin{array}{c}\text { Range } \\
\%\end{array}$ & - & - & - & $\begin{array}{c}0 \text { to } 10 \\
0.87\end{array}$ & $\begin{array}{c}0 \text { to } 10 \\
2.21\end{array}$ & 1 & 267 & $\begin{array}{c}31.19 \\
p<0.001\end{array}$ \\
\hline $\begin{array}{l}\text { Experience: } \\
\text { Acquaintance } \\
\text { with injured } \\
\text { person (yes/no) }\end{array}$ & Yes $\%$ & 4.0 & 9.6 & 8.7 & 8.6 & 55.0 & 4 & - & $\begin{array}{c}0.012 \\
p<0.001\end{array}$ \\
\hline $\begin{array}{l}\text { Experience: } \\
\text { Sighting (yes/no) }\end{array}$ & Yes\% & 8.0 & 19.2 & 14.1 & 24.0 & 89.6 & 4 & - & $p<0.001$ \\
\hline Attitude & Range & -2 to 10 & -4 to 10 & -2 to 8 & -10 to 9 & -5 to 8 & 4 & 458 & 10.64 \\
\hline$(-10$ to 10$)$ & Mean \pm SD & $3.72 \pm 2.62^{\mathrm{a}}$ & $4.35 \pm 3.06^{\mathrm{a}}$ & $2.37 \pm 2.12^{\mathrm{b}}$ & $1.82 \pm 3.12^{\mathrm{b}}$ & $2.83 \pm 3.32^{\mathrm{b}}$ & & & $p<0.001$ \\
\hline Knowledge & Range & 1 to 6 & $\begin{array}{c}1 \text { to } 4 \\
206+078 \mathrm{ab}\end{array}$ & 1 to 6 & 1 to 7 & $\begin{array}{c}3 \text { to } 7 \\
51\end{array}$ & 4 & 458 & 99.74 \\
\hline $\begin{array}{l}(0 \text { to } 7) \\
\text { Perception of } \\
\text { change in jaguar } \\
\text { abundance } \\
(-2 \text { to } 2)\end{array}$ & $\begin{array}{c}\text { Mean } \pm \text { SD } \\
\text { Range } \\
\text { Mean } \pm \text { SD }\end{array}$ & $\begin{array}{c}2.51 \pm 1.05^{\mathrm{a}} \\
-\end{array}$ & $\begin{array}{c}2.06 \pm 0.78^{\mathrm{ab}} \\
-\end{array}$ & $\begin{array}{c}1.86 \pm 1.17^{\mathrm{b}} \\
-2 \text { to } 0 \\
-1.18 \pm 0.37^{\mathrm{a}}\end{array}$ & $\begin{array}{c}3.30 \pm 1.22^{\mathrm{c}} \\
-2 \text { to } 1 \\
-0.72 \pm 0.44^{\mathrm{b}}\end{array}$ & $\begin{array}{c}5.51 \pm 0.87^{\mathrm{d}} \\
0 \text { to } 2 \\
1.32 \pm 0.69^{\mathrm{c}}\end{array}$ & 2 & 358 & $\begin{array}{c}p<0.001 \\
480.68 \\
p<0.001\end{array}$ \\
\hline $\begin{array}{l}\text { Perception of the } \\
\text { economic } \\
\text { situation } \\
\text { (-4 to } 4)\end{array}$ & $\begin{array}{c}\text { Range } \\
\text { Mean } \pm \text { SD }\end{array}$ & - & - & $\begin{array}{c}-2 \text { to } 2 \\
-0.03 \pm 0.54^{\mathrm{a}}\end{array}$ & $\begin{array}{c}-3 \text { to } 2 \\
-0.58 \pm 1.08^{b}\end{array}$ & $\begin{array}{c}-4 \text { to } 4 \\
-1.22 \pm 2.54^{\mathrm{c}}\end{array}$ & 2 & 358 & $\begin{array}{c}14.04 \\
p<0.001\end{array}$ \\
\hline
\end{tabular}




\subsubsection{Socio-economic variables}

The sample of Pantanal ranchers differed from the other groups for being older and composed exclusively by men. In contrast, in urban Pantanal more than $40 \%$ of the respondents were female. Urban residents had higher levels of education than rural residents. Property size varied greatly across groups: the average ranch in the Pantanal was much larger than the average ranch in Amazonia, which in turn was larger than the average farm in the region.

\subsection{Predicting perceptions of jaguar impact on human livelihood}

\subsubsection{Ranchers in Amazonia}

As expected, reported livestock loss was a significant predictor of perceived impact of jaguars on livestock (Table 3; Model 1). In support of Hypothesis 4, cattle ranchers who reported higher losses of cattle to jaguars held stronger perceptions of the impact of jaguars on livestock. However, in accordance with Hypothesis 5, the inclusion of psychological variables (Model 2) accounted for 25\% of the variation $\left(\mathrm{R}^{2}=0.444\right.$ against 0.188$)$ over and above reported livestock loss. Attitude toward jaguars, knowledge about jaguars and depredation emerged as significant predictors of perception of jaguar impact on livestock. Attitudes interacted with knowledge in their effect on perception of jaguar impact on livestock: the higher the knowledge score, the smaller was the effect of attitude on the perception. At higher knowledge scores $(>5)$, attitudes did not predict perceived impact on livestock (GLM; $\beta=-0.08, p=0.399$ ).

Table 3. General linear model predicting perception of jaguar impact on livestock in Amazonia. Results shown in bold are significant.

\begin{tabular}{c|lccccc}
\hline Model & \multicolumn{1}{|c}{ Predictor included } & $R^{2}$ & $\beta$ & SE & $t$ & $p$ \\
\hline \multirow{2}{*}{2} & Reported livestock loss & 0.188 & $\mathbf{1 . 3 9 3}$ & $\mathbf{0 . 1 9 6}$ & $\mathbf{7 . 1 1 0}$ & $<\mathbf{0 . 0 0 1}$ \\
& Acquaintance with injured people & & -0.044 & 0.566 & -0.078 & 0.938 \\
\hline 2 & Reported livestock loss & 0.444 & $\mathbf{0 . 8 3 3}$ & $\mathbf{0 . 1 7 5}$ & $\mathbf{4 . 7 6 4}$ & $<\mathbf{0 . 0 0 1}$ \\
& Attitude & & $\mathbf{- 0 . 6 7 4}$ & $\mathbf{0 . 1 0 0}$ & $\mathbf{- 6 . 7 0 4}$ & $<\mathbf{0 . 0 0 1}$ \\
& Knowledge & & $\mathbf{- 0 . 5 5 9}$ & $\mathbf{0 . 1 3 6}$ & $\mathbf{- 4 . 1 1 5}$ & $<\mathbf{0 . 0 0 1}$ \\
& Attitude x knowledge & $\mathbf{0 . 1 0 6}$ & $\mathbf{0 . 0 3 1}$ & $\mathbf{3 . 4 7 5}$ & $\mathbf{0 . 0 0 1}$ \\
& Sighting & -0.245 & 0.318 & -0.770 & 0.442 \\
& Perception of change in abundance & & 0.283 & 0.306 & 0.924 & 0.356 \\
& Perception of economic situation & & -0.023 & 0.124 & -0.184 & 0.854 \\
\hline 3 & Reported livestock loss & 0.450 & $\mathbf{0 . 8 2 8}$ & $\mathbf{0 . 1 7 4}$ & $\mathbf{4 . 7 5 1}$ & $<\mathbf{0 . 0 0 1}$ \\
& Attitude & & $\mathbf{- 0 . 6 5 8}$ & $\mathbf{0 . 1 0 0}$ & $\mathbf{- 6 . 5 8 1}$ & $<\mathbf{0 . 0 0 1}$ \\
& Knowledge & & $\mathbf{- 0 . 5 5 7}$ & $\mathbf{0 . 1 3 9}$ & $\mathbf{- 3 . 9 9 6}$ & $<\mathbf{0 . 0 0 1}$ \\
& Attitude x knowledge & $\mathbf{0 . 1 0 5}$ & $\mathbf{0 . 0 3 0}$ & $\mathbf{3 . 4 7 4}$ & $\mathbf{0 . 0 0 1}$ \\
& Age & & 0.010 & 0.011 & 0.922 & 0.358 \\
& Gender & & 0.208 & 0.312 & 0.668 & 0.505 \\
& Education & & 0.184 & 0.182 & 1.012 & 0.313 \\
& Property size & $<-0.001$ & $<0.001$ & -0.017 & 0.987 \\
\hline
\end{tabular}

Negative experiences (reported livestock loss and acquaintance with injured people) did not affect perception of jaguar impact on human safety in Amazonia (Model 1), in contrast to Hypothesis 4. Perception of jaguar impact on human safety was predicted only by attitude and knowledge (GLM; $\beta=-0.221, p=0.049$ and $\beta=-0.352, p=0.022$, respectively, $R 2=0.110)$ (Model 2): the more negative the attitudes towards jaguars and the lower the knowledge about jaguars and depredation, the stronger the perception of the impact of jaguars in human safety, in support of Hypothesis 5. Age, gender and property size were significant predictors of attitude (age: $\beta=-0.054, p=0.001, \mathrm{R} 2=$ 0.061 ) and knowledge (gender: $\beta=0.694, \mathrm{p}<0.001$ and property size: $\beta<0.001, \mathrm{p}<0.001, \mathrm{R} 2=$ 0.176), supporting Hypothesis 6. Fig.2a summarizes the above findings. 


\subsubsection{Ranchers in the Pantanal}

As expected, livestock loss significantly affected perceptions of jaguar impact on livestock also in the Pantanal (Model 1; Table 4). Perceived impact of jaguars on livestock was stronger among ranchers who had reportedly lost more cattle to jaguars, which supports Hypothesis 4. However, attitude and perception of economic situation emerged as significant predictors of perception of jaguar impact on livestock, in accordance with Hypothesis 5. The inclusion of age, education and property size (Model 3) accounted for only $0.6 \%$ of the variation in perception of jaguar impact on livestock and none of the socio-economic variables was a significant predictor of perception.

Table 4. General linear model predicting perception of jaguar impact on livestock in the Pantanal. Results shown in bold are significant.

\begin{tabular}{c|lccccc}
\hline Model & \multicolumn{1}{|c}{ Predictor included } & $R^{2}$ & $\beta$ & SE & $t$ & $p$ \\
\hline \multirow{2}{*}{2} & Reported livestock loss & 0.262 & $\mathbf{1 . 3 7 4}$ & $\mathbf{0 . 3 4 4}$ & $\mathbf{3 . 9 9 3}$ & $<\mathbf{0 . 0 0 1}$ \\
& Acquaintance with injured people & & -0.519 & 0.569 & -0.912 & 0.367 \\
\hline \multirow{2}{*}{ Reported livestock loss } & 0.668 & $\mathbf{0 . 6 9 5}$ & $\mathbf{0 . 2 5 5}$ & $\mathbf{2 . 7 3 1}$ & $\mathbf{0 . 0 0 9}$ \\
& Attitude & & $\mathbf{- 0 . 2 8 5}$ & $\mathbf{0 . 0 8 8}$ & $\mathbf{- 3 . 2 5 6}$ & $\mathbf{0 . 0 0 2}$ \\
& Knowledge & & 0.114 & 0.309 & 0.370 & 0.713 \\
& Sighting & 0.859 & 0.893 & 0.961 & 0.342 \\
& Perception of change in abundance & & 0.797 & 0.467 & 1.704 & 0.095 \\
& Perception of economic situation & & $\mathbf{- 0 . 4 3 9}$ & $\mathbf{0 . 1 2 8}$ & $\mathbf{- 3 . 4 3 4}$ & $\mathbf{0 . 0 0 1}$ \\
\hline 3 & Reported livestock loss & 0.674 & $\mathbf{0 . 8 2 4}$ & $\mathbf{0 . 2 6 4}$ & $\mathbf{3 . 1 1 9}$ & $\mathbf{0 . 0 0 3}$ \\
& Attitude & & $\mathbf{- 0 . 2 3 7}$ & $\mathbf{0 . 0 9 8}$ & $\mathbf{- 2 . 4 2 5}$ & $\mathbf{0 . 0 2 0}$ \\
& Perception of change in abundance & & 0.894 & 0.480 & 1.863 & 0.070 \\
& Perception of economic situation & & $\mathbf{- 0 . 3 7 0}$ & $\mathbf{0 . 1 2 7}$ & $\mathbf{- 2 . 9 1 1}$ & $\mathbf{0 . 0 0 6}$ \\
& Age & & 0.031 & 0.025 & 1.213 & 0.232 \\
& Education & & 0.072 & 0.188 & 0.385 & 0.703 \\
& Property size & & $<-0.001$ & $<0.001$ & -0.273 & 0.786 \\
\hline
\end{tabular}

Regarding the perceptions of jaguar impact on human safety, negative experiences with jaguars were not significant predictors (Model 1), in contrast to Hypothesis 4. In partial support for Hypothesis 5, ranchers who were more knowledgeable about jaguars perceived a lower impact of jaguars on human safety. Socio-economic factors (Model 3) did not affect perceptions of the impact of jaguars on human safety. However, in partial support of Hypothesis 6 , age affected attitude to jaguars $(\beta=-$ $0.095, p=0.017, \mathrm{R}^{2}=0.057$ ): older respondents had more negative attitudes towards jaguars. The above findings are summarized in Fig. $2 \mathrm{~b}$. 
a)

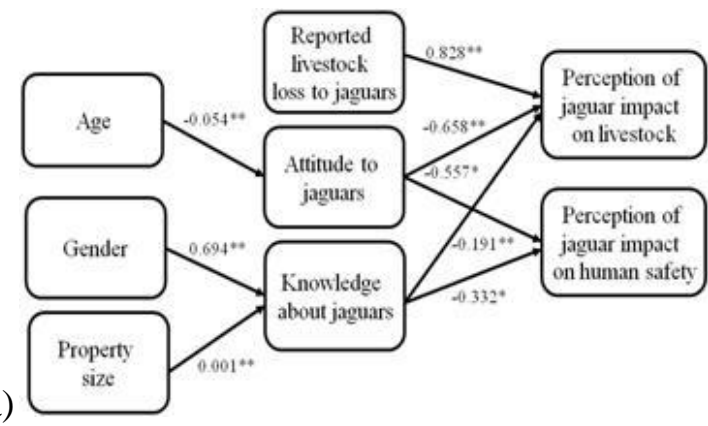

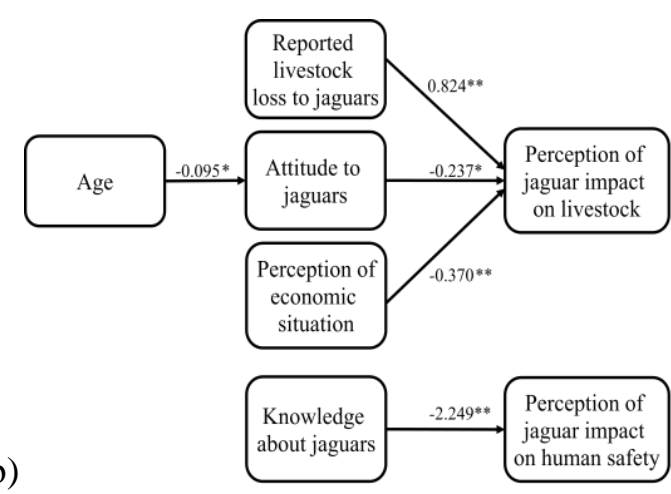

Fig. 2. Final models showing perceptions of jaguar impact on human livelihoods in the Amazonia (a) and Pantanal (b) surveyed site, State of Mato Grosso, Brazil.

\subsection{Photograph interpretation experiment}

In the Pantanal, respondents assigned between four and eight of the ten photographs to jaguar depredation (mean $5.53 \pm \mathrm{SD} 1.187, n=15$ ), while in Amazonia, respondents assigned between zero and ten photos (mean $5.07 \pm \mathrm{SD} 1.704, n=56$ ). The number of photographs assigned to jaguar predation in the Pantanal was not predicted by reported livestock loss, attitudes towards jaguars, or knowledge of the species. In contrast, in Amazonia, while the number of photographs was also not predicted by livestock loss $(\beta=.015, p=.945$, Eta $=.000)$ or knowledge $(\beta=.055, p=.764$, Eta $=$ $.002)$, it was predicted by attitudes $(\beta=-.47, p<.001)\left[\right.$ Adj. $\left.R^{2}=.31, F=7.201\right]$. Respondents who had more negative attitudes towards jaguars assigned a larger number of photographs to jaguar predation. There was a significant interaction between attitudes and knowledge in Amazonia ( $\beta=$ $.047, p=.046$ ); the effect of attitude on the number of photographs assigned to jaguar predation was stronger when knowledge about jaguar and depredation was lower, with attitudes influencing the number of photographs assigned to jaguar depredation for knowledge scores 1 and 2 only.

\section{Discussion and conclusions}

We examined the drivers of perceptions of jaguar impact on human livelihood and identified two distinct dimensions in our sample: impact on livestock and impact on human safety. These can best be addressed separately. We found that perceived jaguar impact on human livelihoods are hugely influenced by region and place of residence, with perceived impact on livestock being greater in the Pantanal, and perceived impact on human safety being greater in the Amazon, and in urban than in rural areas. Reported livestock loss is not the only predictor of perceived jaguar impact on livestock. Rather, experience of losses may act in combination with attitudes, knowledge and perceptions of the economic situation, to determine how people perceive the impact that jaguars have on their livestock. Perhaps surprisingly, professed acquaintance with somebody injured by a jaguar was not a factor in perceptions of jaguar impact on human safety, and urban residents were more afraid of jaguars than ranchers and farmers. Again, perceptions of impact were governed by knowledge about jaguars and depredation and by attitudes towards the species.

In some cases, an impact is perceived even in the absence of any livestock loss to jaguars or jaguar attack on people. Attitudes and knowledge, in turn, are influenced by a person's age, gender, property size (reflecting relative wealth), and place of residence. This is evidence that ecological, cultural and socio-economic context all play roles in the relationships between reality and perceptions behind the conflicts between people and jaguars. 
As expected, perception of jaguar impact on livestock was predicted by livestock loss. However, the perceptions held by ranchers regarding trends in jaguar abundance and in the regional economic situation were also related to their perception of jaguar impact on livestock in the Pantanal. While the suggestion that jaguar numbers are increasing is controversial among government officials, environmentalists and livestock producers (Cavalcanti et al., 2012b), many ranch owners and cowboys claim that jaguar numbers have increased, and hearing that jaguar numbers are growing is likely to cause ranchers to perceive an increasing threat to their cattle. As for the perceived decline in the regional economic situation, over recent decades, growing competition within the cattle industry, higher taxes, and generational land-splitting have rendered cattle-ranching less profitable in the Pantanal. A perceived decline in the financial margins of profits from cattle ranching may decrease ranchers' tolerance of jaguar depredation on their cattle.

Attitudes toward jaguars were important predictors of conflict over livestock in both Amazonia and Pantanal, whereas knowledge appeared to be relevant in Amazonia only. While it is obvious that livestock loss to jaguars is likely to engender negative attitudes towards the species, our photograph interpretation experiment indicated that, in Amazonia, attitudes towards jaguars, and poor levels of knowledge about them, prejudice subsequent judgments in ways that have the potential to become self-reinforcing. Ranchers who had more negative attitudes towards jaguars and less knowledge about them ascribed jaguar depredation as the cause of death to a larger number of photographs, strongly suggesting that their judgments would be similarly prejudiced in the field. Such a phenomenon could in turn affect the number of reports of livestock lost to jaguars, leading to a vicious circle of exaggerated perceptions. An interesting question might be whether this could work the other way around, if conservation-minded people underestimated depredation (see Amit \& Jacobson 2017 for a typology of ranchers based on their thoughts and actions towards jaguars).

The owners of smaller properties in Amazonia had worse attitudes towards and poorer knowledge about jaguars and these, in turn, affected their perceptions of jaguar impact on both livestock and on human safety. Hostility might be partly attributable to smaller holdings having more marginal economic viability, but the finding that attitudes did not differ between small landowners who did or did not raise cattle suggests that their heightened hostility is more likely associated with their poorer education. Furthermore, the owners of small properties tended to believe that depredation problems were more serious on neighboring ranches than on their own. In a landscape dominated by small properties, a patchy distribution of depredation may give disproportionate weight to rumors, especially if a few properties may be severely and repeatedly affected. Certainly, the impact of a few episodes that take on widespread perceptions was vividly illustrated in the context of the threat posed by jaguars to human safety: in each study region there was one instance of a (non-fatal) jaguar attack - in both cases more than five years earlier - and these were repeatedly cited as the basis of negative perceptions. Macdonald (1987) describes similarly how accounts of serious attacks by foxes, Vulpes vulpes, on lambs in the north of England often turned out to refer to the folkloric experiences of other people long ago. In sum, perceptions of conflict with jaguars on small properties are shaped primarily by what is heard from other people and not by personal experience.

By contrasting Amazonia and Pantanal, rural and urban residents, cattle ranchers and crop farmers, and by surveying a wide range of property sizes, this study is the first attempt to understand what is universal in human-jaguar relationships and what is context-specific. Attitudes to jaguars, for instance, affected perceptions of human-jaguar conflict in both Amazonia and the Pantanal, while perceptions of the economic situation were relevant only among ranchers in the Pantanal. Insights of this sort can guide conservation policy regarding the likelihood that interventions found to be successful in one region or socio-economic and cultural context are likely to be transferable elsewhere.

Efforts to protect jaguars have generally been based on the assumption that people are motivated to kill jaguars in retaliation for livestock-raiding. According to this rationale, if ways could be found effectively to reduce jaguar predation on cattle (e.g., adoption of certain husbandry practices, use of electric fences, aversive conditioning and translocation), then persecution by cattle ranchers 
should subsequently decline (Cavalcanti et al., 2012a). Interventions to decrease depredation combined with monetary compensation to ameliorate the financial costs of lost livestock, are intended to alleviate the economic burden imposed on ranchers by sharing the land with jaguars. The assumption is that this compensation will reduce the motivation for ranchers to kill them. However, the finding that perceived impact of jaguars on human livelihood is neither always nor only determined by livestock loss, and that opinions are much influenced by attitudes towards jaguars and knowledge of the species, suggest that conservation interventions should not assume a simple cause and effect relationship. Hitching conservation interventions too simply to the logic of a financial costbenefit analysis may miss the deep-seated, and sometimes prejudiced, human dimension (Marchini and Macdonald, 2012; Dickman et al., 2013). Indeed, the lack of interdisciplinary training within wildlife management and conservation has constrained the understanding of the human dimension of human-wildlife conflicts. Capacity building in human dimensions of wildlife should be a priority in jaguar conservation so that more effective, interdisciplinary approaches that integrate natural, social, and behavioral sciences can be properly incorporated into research, conservation, management, and public policy.

This study reveals the relatively great importance of attitudes and knowledge in the perceived conflict with jaguars on smaller properties (where owners are generally poorer and less educated). Small properties have been relatively overlooked in jaguar research and conservation in Brazil. In Amazonia, however, family-based farms represent $85.4 \%$ of all rural properties and cover $37.5 \%$ of the total area (85\% and 30.5\% for Brazil in general, respectively)(Brondizio et al. 2009). Small landowners in Amazonia are likely less prone to comply with the law that prohibits the clearance of more than $20 \%$ of the property area. Collectively, small properties form expanses of highly degraded jaguar habitat, where low availability of native prey and high human density can increase the chances of a jaguar taking cattle or encountering people, which enhances the perception of conflict (and certainly decreases the jaguar's prospects of survival). This might be particularly true in the Caatinga and Atlantic Forest, where poverty and local resentment towards park authorities (Engel et al. 2016, Engel et al. 2017) among small landowners, respectively, can exacerbate intolerance to the already highly threatened jaguar populations in these biomes (Galetti et al., 2013; Morato et al., 2014; Paviolo et al., 2016). These landscapes merit higher priority in conservation strategy, and would benefit particularly from technical support and incentives, as well as communication campaigns focusing on the realities of risk and using the leverage of influential community institutions and informal social networks - in short, the very conduits through which inaccurate perceptions of jaguars are currently fueled.

\section{Acknowledgements}

We gratefully acknowledge the advice of P. Johnson and the comments of S.E. Baker and A.J. Dickman. This study was possible thanks to support from Cristalino Ecological Foundation, Anglo American Brazil, Instituto HSBC Solidariedade, O Boticário Foundation, Rainforest Concern, Cleveland Metroparks Zoo, Woodland Park Zoo, Chester Zoo, Fauna \& Flora International, the generosity of K. Duncan, and assistance from C. Vicenti. 


\section{References}

Amit, R., Jacobson, S. K., 2017. Understanding rancher coexistence with jaguars and pumas: a typology for conservation practice. Biodiversity and Conservation, 26(6), 1353-1374. DOI: 10.1007/s10531-017-1304-1

Brazilian Institute of Geography and Statistics, 2016. Agricultural census and population estimate. http://http://cidades.ibge.gov.br/ (accessed 20.05.17).

Brondízio, E. S., Cak, A., Caldas, M. M., Mena, C., Bilsborrow, R., Futemma, C. T., Batistella, M., 2009. Small farmers and deforestation in Amazonia. Geophysical Monograph Series, 186, 117-143. DOI: 10.1029/2008GM000716

Bruskotter, J.T., Wilson, R.S., 2013. Determining where the wild things will be: using psychological theory to find tolerance for large carnivores. Conserv. Lett. 7(3), 158-165. DOI:10.1111/conl.12072

Cavalcanti, S.M.C., Crawshaw, P.G. Jr., Tortato, F.R., 2012a. Use of Electric Fencing and Associated Measures as Deterrents to Jaguar Predation on Cattle in the Pantanal of Brazil, in: Somers, M.J. and Hayward, M.W. (Eds.), Fencing for Conservation: Restriction of Evolutionary Potential or a Riposte to Threatening Processes? Springer, New York, pp. 295-309.

Cavalcanti, S.M.C., Azevedo, F.C.C., Tomás, W.M., Boulhosa, R.L.P., Crawshaw, P.G. Jr., 2012b. The status of the jaguar in the Pantanal. Cat News. Special Issue 7, 29-34.

Cavalcanti, S.M., Marchini, S., Zimmermann, A., Giese, E., Macdonald, D.W., 2010. Jaguars, livestock and people: reality and perceptions behind the conflicts in Brazil, in Macdonald, D.W. and Loveridge, A. (Eds.), The Biology and Conservation of Wild Felids. Oxford Press, Oxford, pp. 383-402.

Conforti, V.A. and Azevedo, F.C.C., 2003. Local perceptions of jaguars (Panthera onca) and pumas (Puma concolor) in the Iguacu National Park, south Brazil. Biol. Conserv.111, 215-221. DOI: 10.1016/S0006-3207(02)00277-X

Conover, M. R., 2002. Resolving human-wildlife conflicts: the science of wildlife damage management. CRC Press.

Dickman, A.J., Marchini, S., Manfredo, M., 2013.The importance of the human dimension in addressing conflict with large carnivores. In: Macdonald, D.W., Willis, K.J. (Eds.), Key topics in conservation biology, vol 2. Wiley-Blackwell, Oxford, pp. 110-126

Engel, M.T., Vaske, J.J., Bath, A.J., Marchini, S., 2016. Predicting Acceptability of Jaguars and Pumas in the Atlantic Forest, Brazil. Hum. Dimens. Wildl. 21, 427-444. DOI:10.1080/10871209.2016.1183731

Engel, M.T., Vaske, J.J., Bath, A.J., Marchini, S., 2017. Attitudes toward jaguars and pumas and the acceptability of killing big cats in the Brazilian Atlantic Forest: An application of the Potential for Conflict Index2. Ambio 1-9. DOI:10.1007/s13280-017-0898-6

Ferreira, J., Aragao, L.E.O.C., Barlow, J., Barreto, P., Berenguer, E., Bustamante, M., Gardner, T.A., Lees, A.C., Lima, A., Louzada, J., Pardini, R., Parry, L., Peres, C.A., Pompeu, P.S., Tabarelli, M., Zuanon, J., 2014. Brazil's environmental leadership at risk. Science (80-. ). 346, 706-707. DOI:10.1126/science.1260194

Galetti, M., Eizirik, E., Beisiegel, B., Ferraz, K., Cavalcanti, S., Srbek-Araujo, A.C., Crawshaw, P., Paviolo, A., Galetti, P.M., Jorge, M.L., Marinho-Filho, J., Vercillo, U., Morato, R., 2013. Atlantic rainforest's jaguars in decline. Science 342, 930.

DOI:10.1126/science.342.6161.930-a

Google Inc., 2009. Google Earth (Version 5.1.3533.1731) [Software]. Available from http://earth.google.com/

Jędrzejewski, W., Carreño, R., Sánchez-Mercado, A., Schmidt, K., Abarca, M., Robinson, H.S., Boede, E.O., Hoogesteijn, R., Viloria, Á.L., Cerda, H., Velásquez, G., Zambrano, S., 2017. Jaguar conflicts and the relative importance of retaliatory killing and hunting for jaguar (Panthera onca) populations in Venezuela. Biol. Conserv. 209, 524-532.

DOI:10.1016/j.biocon.2017.03.025 
Kansky, R., Kidd, M., Knight, A.T., 2016. A wildlife tolerance model and case study for understanding human wildlife conflicts. Biol. Conserv. 201, 137-145. DOI:10.1016/j.biocon.2016.07.002

Macdonald, D.W., 1987. Running with the Fox. Unwin Hyman, London.

Manfredo, M.J., 2008. Who Cares About Wildlife? Social Science Concepts for Exploring HumanWildlife Relationships and Conservation Issues. Springer, New York.

Marchini, S., 2003. Pantanal: opiniao publica local sobre meio ambiente e desenvolvimento. Wildlife Conservation Society, Rio de Janeiro, Brazil.

Marchini, S., Crawshaw, P.G., 2015. Human-Wildlife Conflicts in Brazil: A Fast-Growing Issue. Hum. Dimens. Wildl. 1-6. DOI:10.1080/10871209.2015.1004145

Marchini, S., Macdonald, D.W., 2012. Predicting ranchers' intention to kill jaguars: Case studies in Amazonia and Pantanal. Biol. Conserv. 147, 213-221. DOI:10.1016/j.biocon.2012.01.002

Michalski, F., Peres, C.A., 2005. Anthropogenic determinants of primate and carnivore local extinctions in a fragmented forest landscape of southern Amazonia. Biol. Conserv.124, 383396. DOI: 10.1016/j.biocon.2005.01.045

Michalski, F., Boulhosa, R.L.P, Faria, A., Peres, C.A., 2006. Human-wildlife conflicts in a fragmented Amazonian forest landscape: determinants of large felid depredation on livestock. Anim. Conserv. 9(2), 179-188. DOI: 10.1111/j.1469-1795.2006.00025.x

Morato, R.G., Ferraz, K.M.P.M.D., De Paula, R.C., Campos, C.B., 2014. Identification of priority conservation areas and potential corridors for Jaguars in the Caatinga Biome, Brazil. PLoS One 9. DOI:10.1371/journal.pone.0092950

Palmeira F., Barrella, W., 2007. Conflitos causados pela predação de rebanhos domésticos por grandes felinos em comunidades quilombolas na Mata Atlântica. Biota Neotropica.7, 119128.

Paviolo, A., De Angelo, C., Ferraz, K.M.P.M.B., Morato, R.G., Martinez Pardo, J., Srbek-Araujo, A.C., Beisiegel, B. de M., Lima, F., Sana, D., Xavier da Silva, M., Velázquez, M.C., Cullen, L., CrawshawJr, P., Jorge, M.L.S.P., Galetti, P.M., Di Bitetti, M.S., de Paula, R.C., Eizirik, E., Aide, T.M., Cruz, P., Perilli, M.L.L., Souza, A.S.M.C., Quiroga, V., Nakano, E., Ramírez Pinto, F., Fernández, S., Costa, S., Moraes Jr, E.A., Azevedo, F., 2016. A biodiversity hotspot losing its top predator: The challenge of jaguar conservation in the Atlantic Forest of South America. Sci. Rep. 6, 37147. DOI:10.1038/srep37147

Porfirio, G., Sarmento, P., Leal, S., Fonseca, C., 2016. How is the jaguar Pantheraonca perceived by local communities along the Paraguay River in the Brazilian Pantanal? Oryx 50, 163-168. DOI: $10.1017 /$ S0030605314000349.

Sanderson, E.W., Redford, K.H., Chetkiewicz, C.L.B., Medellin, R.A., Rabinowitz, A., Robinson, J.G., Taber, A., 2002. Planning to save a species: the jaguar as a model. Conser. Biol. 16(1), 58-72. DOI: $10.1046 / \mathrm{j} .1523-1739.2002 .00352 . x$

Santos, F.R., Jacomo, A.T.A., Silveira, L., 2008. Humans and jaguars in five Brazilian biomes: same country, different perceptions. Cat News, Special Issue 4, 21-25.

Treves, A., Bruskotter, J., 2014. Ecology. Tolerance for predatory wildlife. Science 344, 476-7. DOI: $10.1126 /$ science. 1252690

Vaske, J.J., 2008. Survey Research and Analysis: Applications in Parks, Recreation and Human Dimensions. Venture Publishing, Pennsylvania.

Zeller, K., 2007. Jaguars in the New Millennium Data Set Update: The State of the Jaguar in 2006. Report. Wildlife Conservation Society. USA. 78pp.

Zimmermann, A., Walpole, M.J., 2005. Cattle ranchers ' attitudes to conflicts with jaguar Panthera onca in the Pantanal of Brazil 39, Oryx 406-412. DOI:10.1017/S0030605305000992 